This item was submitted to Loughborough's Research Repository by the author.

Items in Figshare are protected by copyright, with all rights reserved, unless otherwise indicated.

\title{
Rethinking learning? Challenging and accommodating neoliberal educational agenda in the integration of Forest School into mainstream educational settings
}

\section{PLEASE CITE THE PUBLISHED VERSION}

https://doi.org/10.1111/geoj.12302

\section{PUBLISHER}

Wiley (C Royal Geographical Society (with the Institute of British Geographers).

\section{VERSION}

AM (Accepted Manuscript)

\section{PUBLISHER STATEMENT}

This is the peer reviewed version of the following article: PIMLOTT-WILSON, H. and COATES, J., 2019. Rethinking learning? Challenging and accommodating neoliberal educational agenda in the integration of Forest School into mainstream educational settings. The Geographical Journal, 185 (3), pp.268-278, which has been published in final form at https://doi.org/10.1111/geoj.12302. This article may be used for noncommercial purposes in accordance with Wiley Terms and Conditions for Use of Self-Archived Versions

\section{LICENCE}

CC BY-NC-ND 4.0

\section{REPOSITORY RECORD}

Pimlott-Wilson, Helena, and Janine Coates. 2019. "Rethinking Learning? Challenging and Accommodating Neoliberal Educational Agenda in the Integration of Forest School into Mainstream Educational Settings". Loughborough University. https://hdl.handle.net/2134/37502. 


\section{Rethinking learning?: Challenging and accommodating neoliberal educational agenda in}

the integration of Forest School into mainstream educational settings

For themed issue: 'Educational Landscapes: Nature, Place and Moral Geographies' The Geographical Journal

\section{Abstract}

A nation's education system plays a key role in future economic competitiveness. Political attention to education has fuelled geographical interest in the role of formal education and informal learning environments in the cultivation of future citizen-workers. To date, formal and informal learning have largely been considered separately, but this paper responds by critically evaluating the intersections between the two spheres. This agenda is pursued through in-depth analysis of two state-funded, mainstream primary schools in the Midlands, UK, which adopt a Forest School programme. Qualitative in nature, the research involved 37 semi-structured interviews with teachers and children in the Foundation class and Year 4 (ages 4-5 and 8-9 respectively). The findings demonstrate that children understand classroom learning to contribute to their future pathways in a credentialised labour market, yet some struggle to frame Forest School activities as educational. Although presented as an antidote to the regimen of the school day, Forest School can thus be justified by some participants in relation to curriculum alignment and the future efficacy of the skills and knowledge acquired. In conclusion, this paper contributes to debates on the intersections of formal and informal education to examine how alternative education can function to counteract the institutionalisation of mainstream settings, whilst paradoxically developing skills in children that are valued by neoliberal states. More broadly, this furthers debates in Geographies of Education about what constitutes valuable learning in the primary school setting, and draws attention to the ways innovations might further exclude children currently disadvantaged in the education system.

Key words: outdoor education; alternative education; forest school; children; nature; primary education 
Dr Helena Pimlott-Wilson (corresponding author)

Geography and Environment

Loughborough University

Loughborough

LE11 3TU

01509222789

h.pimlott-wilson@lboro.ac.uk

Dr Janine K. Coates

School of Sport, Exercise and Health Sciences

Loughborough University

Loughborough

LE11 3TU

01509226442

J.K.Coates@lboro.ac.uk 
Rethinking learning?: Challenging and accommodating neoliberal educational agenda in the integration of Forest School into mainstream educational settings

\section{Introduction}

Education is a key element of policy in advanced economies, driven by the desire to promote national economic competitiveness and foster self-reliant citizen-workers of the future (Jenson and Saint-Martin, 2006; Mitchell, 2018). Political attempts to prepare children and young people for future employment have given rise to education systems with increased expectations throughout the school journey (Kraftl, 2015; Ofsted, 2017; PimlottWilson, 2017). In response, alternative educational approaches have grown including Steiner schools, Montessori schools and home schooling ${ }^{1}$. This paper engages with recent work within Geographies of Education which has contested the dichotomy between formal and informal education (Mills and Waite, 2018; Holloway and Kirby, forthcoming) to analyse the utilisation of alternative approaches in mainstream schooling. The purpose of this paper is to explore the integration of formal and informal education, and the consequences for children's experiences of learning.

The paper begins by examining shifts within formal education which have given rise to the growth of informal, alternative approaches and how these have been brought together in mainstream classrooms. The subsequent section outlines the methodology for the research reported in the paper, which involved interviews with children and school staff in

\footnotetext{
${ }^{1}$ Montessori is a system of education that strives to develop children's natural interests and involves selfdirected activities. Steiner schools seek to cultivate pupils' intellectual, artistic and practical skills in a holistic manner. Both promote a connection between children and the environment.
} 
the East Midlands, UK. The central section of the paper focuses on the fusion of classroom and Forest School learning and the challenges which alternative approaches pose for classroom pedagogy. Despite the meeting of the two fields disrupting established practice, neoliberal justifications of learning in the production of future citizen-workers prevail. In conclusion, the paper contributes to debates on the intersections of informal and formal education within Geographies of Education. Novel insights reveal the forms of knowledge which children perceive to be valuable within the education system and the skills which are neglected. Furthermore, the paper raises questions about the influence of the government's inspection regime which leads some schools to implement a further diversified offering when others cannot. This uneven landscape of alternative provision has implications for existing educational inequalities, leaving some children further disadvantaged by the education system.

\section{Neoliberalising education}

Contemporary processes of socio-economic transformation present challenges for the nation state. As governments strive to enhance their position in the global economic order, the preparedness of citizens is fundamental to the achievement of this goal. In neoliberal states, children are embraced as a resource, equipped for their future role as productive, self-reliant citizens through the knowledge, skills and values conferred through the education system (Jenson and Saint-Martin, 2006; Mitchell, 2018). In England, the Early 
Years Foundation Stage (EYFS) framework applies to all schools and Ofsted ${ }^{2}$-registered early years providers (including childminders, preschools, nurseries and school Reception classes). It sets standards for the learning, development and care of children from birth to 5 years old. Child-centred teaching approaches are key to the EYFS, yet there is growing Government attention paid to the school-readiness of children in the Reception year (age 4$5)^{3}$. Schools epitomising 'success' at this stage were reported to give "reading, writing and mathematics in the Reception classes sufficient teaching time every day...so that children were equipped to meet the challenges of Year 1 and beyond" (Ofsted, 2017: 4). As part of this attention to children's early educational outcomes, their development is assessed at the end of Reception Year (in which children turn five) against 17 Early Learning Goals, which include reading, writing and mathematics (Standards and Testing Agency, 2018). This increased formalisation of Reception is argued to prioritise the measurement and tracking of young children's learning in order to prepare them for their future in the school system (Bradbury, 2018).

Following the introduction of the Education Reform Act (1988), a National Curriculum was introduced in all state schools in England, Wales and Northern Ireland, applying to children from Year 1 (age 5-6) through to Year 11 (age 15-16). In the intervening years, this framework has undergone significant change including the increased expectations of the 2014 National Curriculum (Ofsted, 2017) and recent overhauls to the GCSE ${ }^{4}$ grading systems which make it more challenging for students to achieve top grades (Ofqual, 2014). Critics of

\footnotetext{
${ }^{2}$ Ofsted is the Office for Standards in Education, Children's Services and Skills. They inspect and regulate services providing education and skills for learners. Maintained schools can be rated 'outstanding', 'good', 'requires improvement' or 'inadequate'.

${ }^{3}$ In England, children are of 'compulsory schooling age' either on 1 January, 1 April or 1 September following their fifth birthday. Reception Year is the final year of the EYFS.

${ }^{4}$ General Certificate of Secondary Education (GCSE) examinations are generally taken in Year 11 (age 15-16).
} 
a constrained National Curriculum suggest it has led to a decline in teacher autonomy, constricted timetables and given rise to a school system which obstructs creativity (Bassey et al, 2013; Claxton, 2013), institutionalising children to be good, neoliberal workers and consumers (Kraftl, 2015; Pimlott-Wilson, 2017; Mitchell, 2018).

The focus on children's readiness for future employment through increased attainment in a limited number of academic subjects conflicts with ideological notions of childhood as a time of play, freedom and spontaneity (Aitken, 2001; Valentine, 2003; Powell, 2009). The right to play is enshrined in the United Nations Convention on the Rights of the Child, and is undertaken "for enjoyment and recreation rather than a serious or practical purpose" whereas 'work' involves "mental or physical effort done in order to achieve a purpose or result" (Oxford, 2018). This contrasts with adulthood's association with work and duty, yet key elements of children's lives, including education and learning, do involve 'work': that of achieving readiness for future responsibilities (Pimlott-Wilson, 2017). Nevertheless, playful engagement with outdoor environments is framed as naturally beneficial to children (Palmer, 2007), buffering against poor social, emotional and physical outcomes (Isenberg and Quisenberry, 1988; Little and Wyver, 2008). The decline of some children's access to outdoor play has been the focus of sustained geographical interest (Karsten, 2005; Woolley and Griffin, 2015), citing parental concerns of risk associated with traffic and stranger danger as eroding outdoor play and limiting children's independent mobility (Valentine and McKendrick, 1997; Holt et al. 2015). The normalised connection between childhood, play and the outdoors has been called into question (Harker, 2005; Christensen et al, 2018) and further work attends to the socially-differentiated nature of 
children's access to a diversity of play environments, including extracurricular activities, indoor spaces and care settings (Holloway and Pimlott-Wilson, 2018).

In the context of increased National Curriculum expectations (Connolly and Haughton, 2017; Ofsted, 2017) and increased progress monitoring (Bradbury, 2018), alternative forms of education which focus on a more personalised, inclusive and democratic approach to learning, including Steiner, home-schooling and care farms, have developed (Kraftl, 2015). These approaches are driven by principles which encourage children to follow their own interests in small-scale, inclusive settings. The growth of alternative learning environments for children, grounded in informal approaches to learning, provide the backdrop to this paper. Accompanying the growth of alternative education has been an attention to informal education within Geographies of Education, where learning is embedded in children's everyday experiences, relies upon dialogue and can be critical of mainstream education (Kraftl, 2013; Kraftl and Mills, 2014).

Informal education focuses on collaborative learning outside the traditional classroom setting, traversing the divide between education and play. The immediate environment is viewed by practitioners to hold learning potential (Waite, Belling et al, 2016). One form of alternative, informal education, Forest School, encourages children's engagement with local woodland areas in order to foster children's problem-solving skills, develop their cooperative abilities and build their confidence, self-motivation and self-esteem (Knight, 2009; O'Brien, 2009). Introduced to the UK from Scandinavia in the 1990s, Forest School provides an opportunity for children to engage in supported risky play in an inclusive environment and aims to foster development beyond academic skills alone ( $O^{\prime}$ Brien and Murray, 2007). Research into outdoor learning suggests that it supports academic achievement and the 
development of confidence, self-esteem and independence (Maynard, 2007; Quibbel, 2017; Coates and Pimlott-Wilson, 2019), positively influencing children's attitudes to outdoor play and environmental awareness (Ridgers et al, 2012; Waite, Belling et al, 2016). Fostering a positive attitude to the environment and a connection with nature, Forest School is a form of outdoor learning which is removed from the physical and pedagogical constraints of the mainstream classroom (Harris, 2018).

Previous research within the field of Geographies of Education has identified a dichotomous divide between formal education (Thiem, 2009) and alternative, informal learning environments (Kraftl, 2013). An emerging body of work traverses this conceptual divide exploring, for example, how neoliberal political discourses permeate informal learning and education (Mills and Waite, 2018) and the socially-differentiated use of supplementary education to increase attainment in formal educational settings (Holloway and Kirby, forthcoming). This paper contributes to this debate, critically evaluating how alternative forms of education are being drawn into mainstream primary schools by exploring children's contrasting and complementary understandings of learning in classroom and woodland environments. In so doing, the paper highlights the rewards and complexities of traversing the informal/formal education dichotomy in the meeting of mainstream and alternative education.

\section{Researching Forest School}

This study of Forest School was undertaken through in-depth interviews with participants in two primary schools in the English Midlands. A purposeful convenience sampling strategy 
was utilised and schools were recruited based on provision of Forest School to at least one year group. Each school had a predominantly White British intake of pupils and in both schools, the proportion of children receiving free school meals and with special educational needs and disabilities was below national averages. In the first school, Rydal Primary ${ }^{5}$, Forest School was outsourced to a local provider at a woodland space within walking distance of the school. This arrangement had existed for ten years and was offered to all 30 Year 4 (aged 8-9 years) pupils simultaneously. The Forest School involved six, weekly oneday sessions in the autumn term and was facilitated by Forest School practitioners, school staff and parent helpers. In the second school, Esthwaite Primary, the class teacher had recently undertaken Forest School training and took her Reception class of 28 children (aged 4-5 years) to local woodland a short drive away from school. Pupils experienced six, weekly half days in the forest, with half the class attending in the autumn term followed by the rest of the class in the spring term. The sessions were supported by a lunchtime supervisor from the school.

The research involved semi-structured interviews with a total of 33 children ${ }^{6}$ asking about their perceptions of classroom learning, outdoor engagement and Forest School experiences in the weeks following completion of their Forest School programme. In-depth interviews with 15 children in Reception year and 18 from Year 4 lasted between 15 and 83 minutes (mean $=45.5$ minutes; $S D=17.6$ ). To facilitate further reflection, the research incorporated activity-based methods including a word association task which utilised photos of the classroom and Forest School setting which children attended. Taking each location in

\footnotetext{
${ }^{5}$ To protect identities, pseudonyms are used throughout for schools and individuals, with identifying information removed.

${ }^{6}$ The study received full institutional ethical approval. Written informed consent was received from parents and assent from children.
} 
turn, participants selected words (either predefined, devising their own or a combination of the two) that they felt applied to each site. These word associations were intended to facilitate further discussion, with the process of selecting and discarding words generating dialogue about each setting. In addition, we interviewed the Forest School practitioner responsible for Year 4 pupils in Rydal Primary, the class teacher who led Forest School sessions in Esthwaite Primary, and the head teacher in both schools. With these interviewees, we explored their experiences and motivations for incorporating Forest School into their setting. The interviews were fully transcribed and subject to phenomenological thematic analysis utilising the Braun-Clarke approach (Braun and Clarke, 2006). This process involved a familiarisation with the data, the independent generation of initial codes by each author and subsequent grouping of codes according to their similarities. Codes were then combined into overarching themes, with each theme capturing an important pattern of response. These were finally brought together and compared by the research team for consistency and rigour (Tracy, 2010; see Coates and Pimlott-Wilson, 2019 for further discussion).

\section{Learning in the Classroom: Working towards the future}

Children in both schools established play and education (as associated with 'work') as opposite components of the school day, confined to discrete periods of time. During lessons, children described a more passive teacher-directed approach to learning which required effort and relied on writing down information. Focused time devoted to reading, writing and mathematics featured in their day, meaning children in both age groups 
distinguished the serious business of learning and work on the one hand, from a 'playful' approach on the other:

When you're playing with toys, it's definitely not learning...learning is if you get told to do your work...playing is fun and work is, some work is hard, some work is really good (Harry, Reception).

Nicola: We normally do lots of work on the tables [at school]...it's just kind of boring... Lucy: It's just boring just sitting there and writing Interviewer: Is it Lucy?

Lucy: Yeah, you just keep writing and writing and writing (Nicola and Lucy, Reception).

The learning which takes place within the classroom was deemed important for future success, with control of their bodies and acquisition of school-sanctioned appropriate norms of behaviour learned in the classroom environment: "in class you've got to stay quiet and then you've got lots of energy waiting inside you and you just can't use it...... it's because we have to learn about things and get lots of education, so for when we're older we know things" (Alice, Year 4). Similarly, sedentary practice within classrooms is seen as preparing future worker-citizens for careers: "sitting still is a good one [word associated with school] because when you're older sometimes, when you're in the office you can't, you have to like sit still a lot" (Kay, Year 4).

The role of education in preparing children for the future is established early in their school careers. The association between work and adulthood in opposition to play and childhood (Aitken, 2001) features in children's accounts and is central to notions of future preparedness for work, yet the playful side of childhood also becomes increasingly confined to defined segments of the school day: 
Learning [at school] is very, very good because, because if you don't learn, you might not be able to do anything when you're a grown up... because, you're not going to play when you're a grown up (Lewis, Reception).

The necessity to prepare for a successful adulthood through inculcating the norms of the workplace conflicts with Western notions of childhood as a time of play (Valentine, 2003; Harker, 2005). Older children identify subject-based, exam-focused learning as central to successful adult futures. In these lessons, knowledge is acquired, retained for future testing and utilised in adulthood:

In a lesson we'd normally sit still ...In ICT, science, geography, you get quite a bit more facts out of that for you to remember...if you get a test at the end of that term, then you've got to have learnt something and you've got to have kept something in your head (Jess, Year 4).

If you don't learn anything, like you're not going to do well in life because you won't know what to do...So like if you have kids, you know how to look after them and teach them things (Florence, Year 4).

In children's accounts, there is evidence of the neoliberal utility of education in creating responsible citizens of the future with the appropriate knowledge for social reproduction, who can contribute to the economy and behave in socially-acceptable ways.

School is for learning because you need to be able to learn things otherwise you won't be like clever or anything ...And why is it important to be clever? So then you can get a job when you're older. And why is it important to be able to get a job? So then you can earn money for like buying a house and things (Molly, Year 4). 
The role of learning in the classroom is rationalised not as part of childhood, but as part of a longer-term strategy towards a self-reliant adult future.

\section{Playing and learning in Forest School}

When reflecting on children's attitudes to the learning which took place in the forest, teaching staff represented Forest School as an antidote to the writing, work and futureorientated character of classroom-based learning:

They [children] probably don't see it [Forest School] as your typical learning, what they perceive to be learning, because they just see reading and writing and maths as learning probably ...I think parents perceive school as what have you learnt today, have you done any reading, have you done any writing, have you done any maths, and that seems to be the main thing. ... You're not tested on any other part of the curriculum... they associate the outdoors with playing, not working (Head Teacher, Esthwaite Primary).

School staff indicate that a focus on testing and the curriculum confer primacy to the work of mainstream school over the experiential learning that occurs through encounters with the outdoors. Similarly, Ofsted recommendations for cultivating high quality writing in Reception children place emphasis on children's posture, pencil grip and sitting correctly at tables (Ofsted, 2017: 7). Reception children in the sample were only four months into their school journey, yet the children's viewpoints reflected the emphasis on the written word, suggesting they had quickly become accustomed to the teaching methods and physical arrangement of the mainstream school classroom: 
Is the forest a place for learning? (shakes head) No? Mmhmm (agreement) Why are you not learning? Because we can't get a table there! Do you need a table for learning? Mmhmm (agreement) Yeah? Why, do you need a table to learn? Because so we don't get a hole in the writing... (discusses writing on paper at a table and the need for paper to learn) And if it's nice and smooth we...(stops speaking) Ah, so we learn when we write things down? Yeah. When we go back to our classroom we can do it...When we're out, we can't learn (Amelia, Reception).

For the older children, there was a clear difference in the teaching approaches in Forest School and mainstream school. Education and work (as a purposeful task) were bound together with the classroom which was positioned as a 'useful' space for future outcomes. This contrasted with the playful, child-led approach in Forest School which challenged children's notions of learning that they had acquired during their time in school. Children recognised that they were acquiring knowledge, but framing it as such proved complex for some because the encounter was less structured and more akin to recreation, or play:

Well, at school you're like learning indoors and you're writing in books, but these, in Forest School it isn't really learning, writing in books; it's like being outdoors and learning how to build dens for example and it's quite different I'd say (Zara, Year 4). Through their dialogues, it became clear that Forest School gave children a chance to engage with hands-on experiential learning. While children framed this new knowledge as 'learning', they also saw this as distinct from curriculum-based 'education'. Summer (Year 4) describes learning as classroom activity where children "normally learn things like numbers and timetables"; whereas Forest School involves learning because it is "not about 
doing lessons, but learning in a fun way". Children recognised Forest School as offering access to knowledge that was different from that acquired in mainstream education both in content and delivery.

Interviewees suggest that learning in Forest School offers an alternative to the 'work' of mainstream education due to its more playful approach. Like Zara and Summer, Florence rationalises Forest School as a playful learning environment removed from the norms of mainstream education in terms of writing down information. However, she continues by justifying the knowledge acquired in relation to curriculum subjects, legitimating the purposeful work undertaken:

It's quite different [from school] because we don't have to do like working, maths, like we're doing maths but we're not writing it down anywhere... We needed to know how many ropes and tarps we needed if we were building our den and we needed to use maths for that... You're actually out playing while learning (Florence, Year 4).

Highlighting the potential synergies between outdoor learning and curriculum subjects acts to legitimise Forest School for some children. In her evaluation of combining Forest School and mainstream education, Mai emphasises the skills of creativity and ingenuity valued in the knowledge economy (Gray, 2016), which are fostered through an alternative learning environment. She also makes connections between hands-on, tactile learning and the outdoors, in opposition to the classroom which is removed from real life:

You can explore the outer world and nature rather than, inside you can just look outside the window and not like touch the real-life stuff and inside you're not. Like in 
like a museum, you're not allowed to touch the real stuff; but you can be creative and make your own stuff outside (Mai, Year 4).

In comparing these divergent learning environments, the majority of children identify a more active, child-led and curious approach in Forest School. For some, their experiences of Forest School challenged the dualism of work and play to suggest they were concurrently playing and learning. Children were clear that they were absorbing purposeful knowledge, such as den building, camping and rope work, yet this learning was seen as less valuable than 'education' i.e. that taught in the classroom setting, unless it could be rationalised in relation to curriculum subjects or held value for the future.

In differentiating mainstream and alternative approaches to education, some children also narrated the outdoor skills and knowledge they were acquiring as useful in pathways to adulthood. Mai frames these skills as preparation for a potential future career engaged with nature, emphasising the neoliberal utility of her experience but also how this can contribute to rounded learning:

It's [Forest School] really important because you're learning new stuff ... about forests and nature, instead of just learning about maths and English at school... [That's important] Because I didn't know much about the nature and I wanted to learn more because I don't know what I want to be when I grow up, so I want to know different types of things so I can decide what I want to do [for a job] (Mai, Year 4).

Harriet gave prominence to her classroom-based education in future pathways but suggested that outdoor education could also be utilised to gain labour market advantages: 
I think we learn more in the classroom, like that's more like things we're going to do when we're older....but...if you wanted to help at Forest School when you get older and you did go there [as a child], it would also be good for your experience and you could put it on your résumé (Harriet, Year 4).

Participants recognise the complementarity of different teaching approaches and knowledge, from writing, reading and arithmetic in the classroom as well as environmental, hands-on skills acquired in Forest School. The notion of developing skills that could be useful in the future was echoed by teaching staff, who recognised the development of social skills, self-confidence and problem-solving as inherent to Forest School. They suggest that these skills are key to the global competitiveness of the country's economy that pervades the government's neoliberal approach to education, yet these skills are overlooked in the curriculum:

I think that ability to think out of the box, the ability to think, you know, to problem solve, to create something that you want that isn't already there, different approaches and ways of looking at things I think are available in a woodland environment that aren't necessarily available in a classroom. Are those skills valued in the curriculum though? Problem solving and creativity? Nowhere near as much as they could be... I think they're valued in the workplace more importantly, aren't they, it's employers, it's life skills as grown-ups... it probably doesn't get as much kind of value in the curriculum as it could, but it doesn't mean just because the curriculum doesn't understand it's important, doesn't mean it's not important (Reception Teacher, Esthwaite Primary). 
Children recognise that Forest School provides them with an environment in which they can gain useful knowledge in a hands-on, playful manner. However, the divergence from established approaches in mainstream school makes it difficult for some children to frame this knowledge as educational. In emphasising the synergies between Forest Schools, the curriculum and future efficacy, children's narratives can act to legitimise the incorporation of informal approaches into the school day.

\section{An alternative to a stifling curriculum?}

Integrating alternative approaches with classroom education exposes the fissures between formal and informal learning to children, whilst also highlighting areas of complementarity. For some children, Forest School represented a break from subject-based, exam-driven and future-orientated teaching. For Alice, classroom education focused upon the acquisition and recital of 'correct' answers, fostering a stressful environment:

So it's [Forest School] not like all tense and lots of questions and then lots of like right answers and wrong answers and different things, and it's nothing like normal school, it's just amazing" (Year 4).

Similarly, Harriet gained knowledge about outdoor survival skills which meant she "felt like I was learning a lot [about camping and shelters], but I also felt free and I wasn't getting wound up as much" (Year 4). While we are cautious to avoid essentialising the relationship between childhood and nature and in turn, idealising outdoor environments as naturally beneficial for children (Palmer, 2007), our respondents expressed a greater sense of 
freedom (physically and mentally) and an ability to express themselves outside of the classroom:

You used the word 'kid-like', do you think school allows you to be kid-like?

Not inside [the classroom]. Like you want to be kid-like like outside because you want to be free and you have more freedom [at Forest School]...you don't have to be trapped inside - you can be your normal self outside (Mai, Year 4).

Other pupils, such as Jack, found attending Forest School provided a stark contrast to the controlled and regimented school day which he found stifling and monotonous:

(When identifying words associated with school): 'Sitting still', they [teachers] make you... 'Boring' because the work is. 'Waste of time' because I already know some stuff what they tell you literally every day... 'Rules', which is just loads of rules, and also 'hard' because it's hard work... [Forest School is different] it's actually really fun because every, every day they do something different... It was, yeah, Forest School was awesome... Learning? You learn that it's a lot better than school (Year 4).

A change in physical environment for Jack thus shifted the relationship with school and Jack's experience of learning in the classroom was echoed by teaching staff. They identified the difficulties that schools face, balancing expectations from government and a constricted curriculum assessed through testing against a more varied approach to learning:

One of the other things about Forest School and the other outdoor learning that takes place, is that it is a release valve actually, because the danger is, and it is a danger and going back to that Ofsted thing as well, the first thing we are held accountable for 
[children's progress against targets], is that schools, primary schools could become pressure cookers, pressure cookers of learning the three Rs, academic learning. So it is a release valve from that regimentation of pure academic learning... Ofsted will say all the right things about it [Forest School] ... but it's all completely underscored, how good are your results? If your results are good, then they'll say wonderful things about it and if your results aren't good, they don't care about it (Head Teacher, Rydal Primary).

The ability to integrate alternative approaches to education into the mainstream was identified by both schools as a virtue of their performance as 'good' schools in Ofsted inspections. Ofsted reports of schools which provide opportunities for learning in the natural environment have noted benefits for pupil progression, enjoyment of learning, and spiritual, moral and cultural development (Waite, Passy et al, 2016), yet educationalists in our study were cautious of the limits to this standpoint. This aligns with representations of schools deemed 'successful' in Ofsted gradings as devoting sufficient time to core academic learning each day, including from Reception (Ofsted, 2017):

teachers are always very anxious about, 'well I didn't get anything in their books for that lesson... how am I going to show what they've done?' because you know the change of, Ofsted focus has changed, so they're coming in now and looking at pupil outcomes rather than teaching... so there's always that kind of concern when you have book scrutinies (Reception Teacher, Esthwaite Primary).

The requirement to evidence children's progress means that some schools face pressure to demonstrate children's learning in a drive to meet inspection requirements. However, children's exposure to informal education has made visible their critiques of contemporary 
learning environments and demonstrated that they enjoy immersion in a more playful (that is, less writing-focused) environment. Drawing approaches found in alternative education into mainstream school settings thus has the potential to disrupt the monotony of classroom learning and foster positive relationships with school (Harris, 2017).

\section{Conclusion}

An emerging body of work in Geographies of Education traverses the conceptual divide between formal and informal learning environments (Holloway and Kirby, forthcoming; Mills and Waite, 2018). This paper contributes to these debates by critically examining alternative education as a challenge to the institutionalisation of mainstream settings, whilst paradoxically developing future-orientated soft skills in children that are valued by neoliberal states. More broadly, this furthers debates in Geographies of Education about what constitutes valuable learning in the primary school setting from the perspective of children.

Extending the analytical frame of Geographies of Education beyond the mainstream on the one hand and its alternative on the other, the paper presents an exploration of their blending. Children were confident in articulating what constituted work in the formal learning environment of the school classroom, the controlled bodily behaviours it required from them, and its long-term orientation towards future outcomes through examinations. By contrast, articulating what they gained from Forest School was difficult for some children, as it challenged the teaching approaches they were accustomed to and thus they either aligned Forest School with recreation/ play or legitimated it in relation to the school 
curriculum. In the short-term, Forest School represents the antithesis of mainstream education for them, with the outdoors providing freedom, tactile learning and self-direction while the classroom was sedentary, writing-focused and purposeful for their future outcomes (see Coates and Pimlott-Wilson, 2019). In a longer-term view, the skills and knowledge gained from Forest School are rationalised by some children through a futureorientated neoliberal lens, moving beyond the notion of the outdoors simply as a space for play, with perceptions of how it might help them in their future pathways. The future value of Forest Schools was also articulated by teachers who not only appreciated the contemporary pleasure it gave children, but also highlighted the soft skills it can foster that are crucial in post-industrial labour markets (Mitchell, 2018). Taken together, the perspectives of children and teachers on the blurring of the formal and informal in the meeting of mainstream and alternative education illustrates how Forest School can enrich children's educational experiences in both the short and long-term, nurturing positive attitudes towards educational institutions, hands-on learning and creativity. Yet the practicalities of blending Forest School approaches with the mainstream can also be challenging. On the one hand, transposing curriculum requirements into an outdoor setting through directed activities with specified learning outcomes undermines the child-led ethos of Forest School and its emphasis on open-ended learning. On the other hand, teachers and practitioners face constraints in the education system including time, financial resources and staffing, to name a few. Illuminating these practical complexities whilst also examining the relative value associated with academic knowledge, practical skills and the capacity for free thinking within the education system and labour market warrants further academic attention. 
Examining the intersections of the formal and informal are crucial to Geographies of Education and this paper makes two broader contributions to the field. Firstly, it forces us to think about what counts as learning and how this takes place. In a context where there is contention over what equates as 'useful' knowledge (Barrow, 2012; Horton and Kraftl, 2005), the paper draws attention to the prominence of the curriculum and knowledge that can be assessed in examinations in children's understandings of learning. Children's narratives draw parallels between Forest School learning and academic subjects, but they also make clear that learning outside the classroom can confer a sense of freedom and influence their attitudes towards learning. In an era of increased National Curriculum expectations (Ofsted, 2017), increased progress monitoring (Bradbury, 2018) and curricula constraints (Connolly and Haughton, 2017), this raises further questions about the forms of knowledge that children understand to be valuable by virtue of their association with key examinations, core curriculum subjects and future employment outcomes. The paper draws attention to the tensions between the relative value of rote learning, creative thinking and practical skills in the education of the future workforce; issues which resonate beyond the English education system as nations seek to achieve aspirations of global competitiveness in uncertain economic times. Approaches to education which fuse independence and an open-ended approach may act to challenge narrow conceptions of credentialised knowledge, fostering the well-rounded, independent free thinkers that are able to respond to future challenges.

Secondly, the paper raises crucial questions about who gains access to formal, informal and blended educational environments, and thus what the consequences of shifting educational processes are for different children. School staff felt that their ability to 
fuse mainstream teaching with alternative approaches was a function of their schools' strong performance within the government's stringent inspection regime, and that this opportunity is more problematic for schools with less positive Ofsted ratings. This results in diverse educational experiences for children, despite the national regulatory framework in place: those children who already benefit from being in well-performing schools have the potential to access a further diversified curriculum, while those in schools considered less successful may not be able to benefit from this broadening of educational experiences. Thus, future research on the potential for alternative approaches to foster skills and knowledge that are valued beyond the curriculum must explore the implications of existing educational inequalities which can leave some children further disadvantaged by the education system. Researchers in the Geographies of Education must thus look inward at the diversity of educational provision within schools, and outward at the implications of this offering for society and the future knowledge economy by exploring the intersections of formal and informal education.

\section{Acknowledgements}

To be added after peer review

\section{References}

Aitken, S. (2001) Geographies of young people: the morally contested spaces of identity. London: Routledge.

Barrow, R. (2012). Radical education: a critique of freeschooling and deschooling. London: Routledge. 
Bassey, M. and 99 others (2013) Gove will bury pupils in facts and rules, The Independent (online), 20 March. Available at https://www.independent.co.uk/voices/letters/lettersgove-will-bury-pupils-in-facts-and-rules-8540741.html

Bradbury, A. (2018) Datafied at four: the role of data in the 'schoolification' of early childhood education in England. Learning, Media and Technology. doi:10.1080/17439884.2018.1511577.

Braun, V, and Clarke, V. (2006) Using thematic analysis in psychology. Qualitative Research in Psychology, 3, 77-101. doi:10.1191/1478088706qp063oa.

Christensen, P., Hadfield-Hill, S., Horton, J. and Kraftl, P. (2018). Children living in sustainable built environment: new urbanisms, new citizens. London: Routledge.

Claxton, G. (2013). What's the point of school? Rediscovering the heart of education. Oxford: One World Publications.

Coates, J.K. and Pimlott-Wilson, H. (2019) Learning while playing: a qualitative exploration of children's experiences of Forest School in the United Kingdom. British Educational Research Journal, 45(1), 21-40. doi: 10.1002/berj.3491

Connolly, M., \& Haughton, C. (2017). The perception, management and performance of risk amongst Forest School educators. British Journal of Sociology of Education, 38(2), 105-124. doi: $10.1080 / 01425692.2015 .1073098$.

Gray, A. (2016). The 10 skills you need to thrive in the Fourth Industrial Revolution. World Economic Forum, $16^{\text {th }}$ January. Available at https://www.weforum.org/agenda/2016/01/the-10-skills-you-need-to-thrive-in-the-fourthindustrial-revolution/ 
Harker, C. (2005) Playing and affective time-spaces. Children's Geographies, 3, 47-62. doi: $10.1080 / 14733280500037182$.

Harris, F. (2017) The nature of learning at forest school: practitioners' perspectives.

Education 3-13, 45(2): 272-291. doi: 10.1080/03004279.2015.1078833.

Harris, F. (2018). Outdoor learning spaces: the case of forest school. Area, 50, 222-231. doi:10.1111/area.12360.

Holloway, S.L. and Kirby, P. (forthcoming). Supplementary education: new geographies of private tuition, class privilege and minority ethnic advancement. (Available on request). Holloway, S.L. and Pimlott-Wilson, H. (2018). Reconceptualising play: Balancing childcare, extra-curricular activities and free play in contemporary childhoods. Transactions of the Institute of British Geographers. doi:10.1111/tran.12230.

Holt, N., Lee, H., \& Millar, C. (2015). 'Eyes on where children play': A retrospective study of active free play. Children's Geographies, 13, 73-88. doi:10.1080/14733285.2013.828449. Horton, J. and Kraftl, P. (2005). Editorial: For more-than-usefulness: six overlapping points about children's geographies. Children's Geographies, 3, 131-143. doi:10.1080/14733280500161503. Isenberg, J. and Quisenberry, N. L. (1988). Play: A necessity for all children. Childhood Education, 64, 138-145. doi:10.1080/00094056.1988.10521522. Jenson, J. and Saint-Martin, D. (2006). Building blocks for a new social architecture: the LEGO $^{\text {TM }}$ paradigm of an active society. Policy and Politics, 34, 429-451. doi:10.1332/030557306777695325. 
Karsten, L. (2005). It all used to be better? Different generations on continuity and change in urban children's daily use of space. Children's Geographies, 3, 275-290.

doi:10.1080/14733280500352912.

Kraftl, P. (2013). Towards geographies of "alternative" education: A case study of UK home schooling families. Transactions of the Institute of British Geographers, 38, 436-450. doi:10.1111/j.1475-5661.2012.00536.x.

Kraftl, P. (2015). Geographies of alternative education: Diverse learning spaces for children and young people. Bristol: Policy Press.

Kraftl, P. and Mills, S. (2014)(Eds.). Informal education, childhood and youth: Geographies, histories, practices. Basingstoke: Palgrave Macmillan.

Knight, S. (2009) Forest schools and outdoor learning in the early years. Sage: London. Little, H. \& Wyver, S. (2008). Outdoor play: Does avoiding the risks reduce the benefits? Australian Journal of Early Childhood, 33, 33-40.

Maynard, T. (2007). Forest Schools in Great Britain: an initial exploration. Contemporary Issues in Early Childhood, 8, 320-331. doi:10.2304/ciec.2007.8.4.320.

Mills, S. and Waite, C. (2018). From Big Society to Shared Society? Geographies of social cohesion and encounter in the UK's National Citizen Service. Geografiska Annaler: Series B, 100, 131-148. doi: 10.1080/04353684.2017.1392229.

Mitchell, K. (2018) Making workers: radical geographies of education. London: Pluto Press O’Brien, L. (2009) Learning outdoors: the Forest School approach. Education 3-13, 37:1, 4560. doi:10.1080/03004270802291798. 
O'Brien, L. and Murray, R. (2007) Forest School and its impacts on young children: Case studies in Britain. Urban Forestry and Urban Greening, 6: 249-265. doi: 10.1016/j.ufug.2007.03.006.

Ofqual (Office of Qualifications and Examinations Regulation)(2014) Completing GCSE, AS and A level reform. Coventry: Ofqual. Available at https://assets.publishing.service.gov.uk/government/uploads/system/uploads/attachment_ data/file/377804/2014-06-24-completing-gcse-as-and-a-level-reform.pdf

Ofsted (2017) Bold beginnings: The Reception curriculum in a sample of good and outstanding primary schools. Available at https://assets.publishing.service.gov.uk/government/uploads/system/uploads/attachment_ data/file/663560/28933_Ofsted_-_Early_Years_Curriculum_Report_-_Accessible.pdf Oxford (2018). Oxford Dictionaries ('work' and 'play'). Retrieved from https://www.oxforddictionaries.com/

Palmer, S. (2007). Toxic childhood: How the modern world is damaging our children and what we can do about it. London: Orion.

Pimlott-Wilson, H. (2017) Individualising the future: the emotional geographies of neoliberal governance in young peoples' aspirations. Area, 49(3): 288-295. doi: 10.1111/area.12222. Powell, S. (2009) The value of play: Constructions of play in government policy in England. Children and Society, 23(1): 29-42. doi: 10.1111/j.1099-0860.2008.00137.x.

Quibell, T., Charlton, J. and Law, J. (2017) Wilderness schooling: a controlled trial of the impact of an outdoor education programme on attainment outcomes in primary school pupils. British Educational Research Journal. 43(3): 572-587. doi:10.1002/berj.3273. 
Ridgers, N. D., Knowles, Z. R., \& Sayers, J. (2012). Encouraging play in the natural environment: A child-focused case study of Forest School. Children's Geographies, 10, 49-65. doi:10.1080/14733285.2011.638176.

Standards and Testing Agency (2018) Early years foundation stage profile: 2019 handbook. London: Standards and Testing Agency. Available at https://assets.publishing.service.gov.uk/government/uploads/system/uploads/attachment_ data/file/762499/EYFS_profile_handbook_2019.pdf

Thiem, C.H. (2009). Thinking through education: The geographies of contemporary educational restructuring. Progress in Human Geography, 33, 154-173. doi:10.1177/0309132508093475.

Tracy, S. J. (2010). Qualitative quality: Eight "big-tent" criteria for excellent qualitative research. Qualitative Inquiry, 16, 837-851. doi:10.1177/1077800410383121.

Valentine, G., \& McKendrick, J. (1997). Children's Outdoor Play: Exploring Parental Concerns about Children's Safety and the Changing Nature of Childhood. Geoforum, 28, 219-235. doi:10.1016/S0016-7185(97)00010-9.

Valentine, G. (2003) Boundary crossings: transitions from childhood to adulthood. Children's Geographies, 1, 37-52. doi: 10.1080/14733280302186.

Waite, S.. Belling, M. and Bentsen, P. (2016). Comparing apples and pears? A conceptual framework for understanding forms of outdoor learning through comparison of English Forest Schools and Danish udeskole. Environmental Education Research, 22, 868-892. doi:10.1080/13504622.2015.1075193. 
Waite, S., Passy, R., Gilchrist, M., Hunt, A. and Blackwell, I. (2016) National connections demonstration project, 2012-2016: Final report. Natural England Commissioned Reports, Number215.

Woolley, H. and Griffin, E. (2015). Decreasing experiences of home range, outdoor spaces, activities and companions: changes across three generations in Sheffield in north England. Children's Geographies, 13, 677-691. doi:10.1080/14733285.2014.952186. 